Acta Technologica Agriculturae 4

Nitra, Slovaca Universitas Agriculturae Nitriae, 2020, pp. 190-194

\title{
DESIGN OF ARTIFICIAL LIGHTING IN BROILER HOUSING
}

\author{
Peter MORVAI*, Miroslav ŽITŇÁK, Jana LENDELOVÁ \\ Slovak University of Agriculture in Nitra, Slovak Republic
}

\begin{abstract}
The work aim is to propose lighting system designs that would satisfy the broiler welfare in terms of intensity; wavelength; switching interval; and energy savings, and would help farmers to reduce the unit costs. BuildingDesign software with Wils 7.0.342 module was used to design suitable lighting, calculate and visualize it. By optimizing the required parameters and energy performance of system, four final designs were prepared with the appropriate evaluation with respect to the acquisition price and return on investment. The original lighting system included a combination of 68 pcs. of tungsten and fluorescent lamps with consumption of $2.17 \mathrm{kWh}$ and a minimum illumination intensity of $7.02 \mathrm{~lx}$. Measurements were conducted at 212 points of the control grid. Artificial lighting is the only light source in an environment of eco-friendly controlled farm. Based on the research analyses, there were proposed four lighting system alternatives with various light intensity; wavelength; switch-on interval; and energy savings. In terms of light intensity, all four designs meet the animal welfare requirements. The most advantageous alternative in the long term is design no. 4 with consumption of $0.734 \mathrm{kWh}$ per one cycle (with energy savings of $66.17 \%$ in contrast to the original lighting), in which the intermittent switching mode showed a power savings of $56 \%$ and lighting intensity regulation of $40 \%$ while maintaining a minimum lighting intensity of $20 \mathrm{~lx}$ (total savings for switching and regulation reached up to $73.7 \%$ ). By utilizing modern approaches, appropriate light colour and lighting quality suitable for broiler breeding were achieved.
\end{abstract}

Keywords: welfare; artificial lighting; broiler breeding; intermittent switching mode; light intensity

Welfare issues can be frequently observed in both conventional and organic production of broiler chickens. In order to efficiently reduce their impacts, it has been suggested to provide stimulating, enriched environments (Riber et al., 2018; Mihina et al., 2012). Furthermore, rearing chicken in high-density environments results in a range of animal welfare problems (Matauschek et al., 2006). As commercial poultry farming has been gaining popularity in recent years, it is necessary to constantly improve the feeding and lighting elements (Pitesky et al., 2019). The only light source for chickens in an environmentally controlled chicken house is artificial lightning. Therefore, light wavelength (quality), light intensity (quantity), and light period (regime) have become major factors in modern poultry management (Yang et al. 2016). As highlighted by Lewis and Gous (2007), broiler chickens have been reared at commercial facilities throughout the past decades with either continuous ( $24 \mathrm{~h}$ of light), or near continuous illumination ( $23 \mathrm{~h}$ light and $1 \mathrm{~h}$ of dark) in order to maximize the feed intake and growth rate. Newberry (1999) defined environmental enrichment as a modification of the environment, in which the captive animals live, thereby increasing their behavioural possibilities and leading to improvements of the biological functions. This means that environmental enrichment is provided with the purpose of:

1. increasing the occurrence and range of the animals' normal or species-specific behaviour;
2. preventing the development of abnormal behaviour or reducing its extent and complexity;

3. increasing the positive exploitation of the environment (e.g. utilization of an outdoor area);

4. increasing the animals' ability to handle behavioural and physiological challenges.

It is emphasized that environmental enrichment must be biologically relevant to be effective. In certain countries, conventional bulbs are commonly used for lighting in poultry halls. Insufficient lightning of poultry farms leads to stress, negative impacts on feed intake and physical activity. Given the favourable effect of green light on performance characteristics, their usage is recommended for broiler chicken production (Gharahveysi et al., 2019). The aim of work was to analyse the current state of intensity and energy balance of the original lighting of the experimental farm, design alternative types and operational solutions and perform overall evaluation of changes in lighting, energy performance and return on investment of individual solutions in favour of improving the broiler breeding conditions.

\section{Material and methods}

The research was carried out at a standardized poultry farm for broiler breeding in the western Slovak lowland. The experimental farm includes six identical halls designed for breeding of broiler chickens ROSS 308. The chickens are

Contact address: Peter Morvai, Slovak University of Agriculture in Nitra, Faculty of Engineering, Department of Building Equipment and Technology Safety, Nitra, Slovakia; e-mail: petermorvai@yahoo.co.uk 
reared in cycles of 32 to 35 days with a break of 14 days between cycles. The lighting measurement experiment was performed in experimental hall 3. The hall length is $101 \mathrm{~m}$; the width including walkways for the operator is $12.6 \mathrm{~m}$; the wall height is 2.3; and the ridge height is $3.8 \mathrm{~m}$ with a total area of $1,010.0 \mathrm{~m}^{2}$. Breeding halls based on steel loadbearing structures and structural insulated sheathing were built in the 1980s in the former Czechoslovakia. In all the experimental farm halls, the feeding system, water supply, heating and ventilation were reconstructed. Furthermore, partial reconstruction of the electrical wiring was carried out. These systems are in a well-maintained and satisfactory condition. External walls, ceiling, floor as well as lighting, are in their original state with minimal interference. For these systems, reconstruction is necessary to improve both animal welfare and building energy efficiency. The original lighting system consists of a combination of 68 pcs. of tungsten and fluorescent lamps with consumption of $2.17 \mathrm{kWh}$ (Morvai, 2019). Artificial lighting is the only light source in an environmentally controlled farm. Sockets with E27 threads (International Protection IP20) are suspended and evenly distributed in four rows. The current state assessment was performed by measuring the illumination and contrasting it with corresponding statistical and general assessment of effectiveness. BuildingDesign software with Wils 7.0.342 module was used to design alternative lighting, calculate and visualize new lighting. The lighting switching interval was selected based on the literature in order to achieve optimal growth parameters. Specific lighting design with respect to energy savings and maintaining given lighting intensity and light colour is a less investigated research field. The proposal consisted of alternatives that would be suitable for the welfare of broiler breeding and would help farmers reduce unit costs while maintaining adequate light intensity, wavelength, switching interval and energy savings. This work pays attention to the design of new lighting with LED (Light Emitting Diode) chips and showing the possible savings of electricity and return on investment by comparing the new design with the original lighting.

\section{Light intensity measurement}

Layout of the luminaries and layout of the control grid for measuring the illumination intensity are shown in Fig. 1. The illumination intensity was measured at a height of $0.2 \mathrm{~m}$ from the floor - animal welfare zone - with five repetitions. The illumination intensity measurement started after stabilization of the luminous flux after the lightning was switched on (approx. after 20 minutes) and was subsequently carried out at checkpoint locations in a regular rectangular grid throughout the entire reference plane or functional parts. Illumination measurement E $(1 \times)$ was carried out in the evening to exclude daylight.

The luxmeter UNI-T UT382 with illumination range of $0-20,000$ lux and accuracy of $\pm 3 \%$ was used for the purposes of illumination measuring. Professional measuring instrument GLM $100 \mathrm{C}$ with measuring range up to $100 \mathrm{~m}$ and accuracy of $\pm 1.5 \mathrm{~mm}$ was used to measure distances indoors. BuildingDesign software was utilized to design, calculate and visualize new lighting.

By means of the BuildingDesign software, 3D geometry of the object was sketched, to which a uniformly distributed system of luminaries and a set of evaluated points for four luminary designs with different intensity and illumination curves were inserted. Minimal values of illumination and uniformity were used for the designs according to the STN EN 12464-1: 2011. Software with active calculation module Wils 7.0.342 calculated lighting system parameters according to the STN EN 12464-1: 2011. Considering the cost calculation of designs, only the lighting system cost (lamp and light source) was taken into account; the power supply system reconstruction (labour and materials) was not included in the final price calculation.

\section{Results and discussion}

\section{Experimental hall original illumination results}

When assessing the lighting in a room, the purpose a given room will serve is crucial (Balková, 2013). By measuring the illumination according to STN EN 13032-1+A1: 2012, the current illumination intensity and critical points with the lowest illumination values were observed. Calculated values are shown in Table 1.

The average illumination provided by the original hall lighting system does not meet the legislative requirements for broiler breeding. Light intensity affects activity, taking rest and food intake. High light intensity extremely increases the movement and stress of chickens (Buyse et al., 1996; Olanrewaju et al., 2011; Xie et al., 2008; Kim et al., 2013). At low light intensity, the animal movement activity is reduced (Hartini et al., 2002, Olanrewaju et al., 2006; Lien et al., 2007). The best results in terms of body weight and FCR (feed conversion ratio) were observed at 50 lux green light. The light colour effect on both haemoglobin and

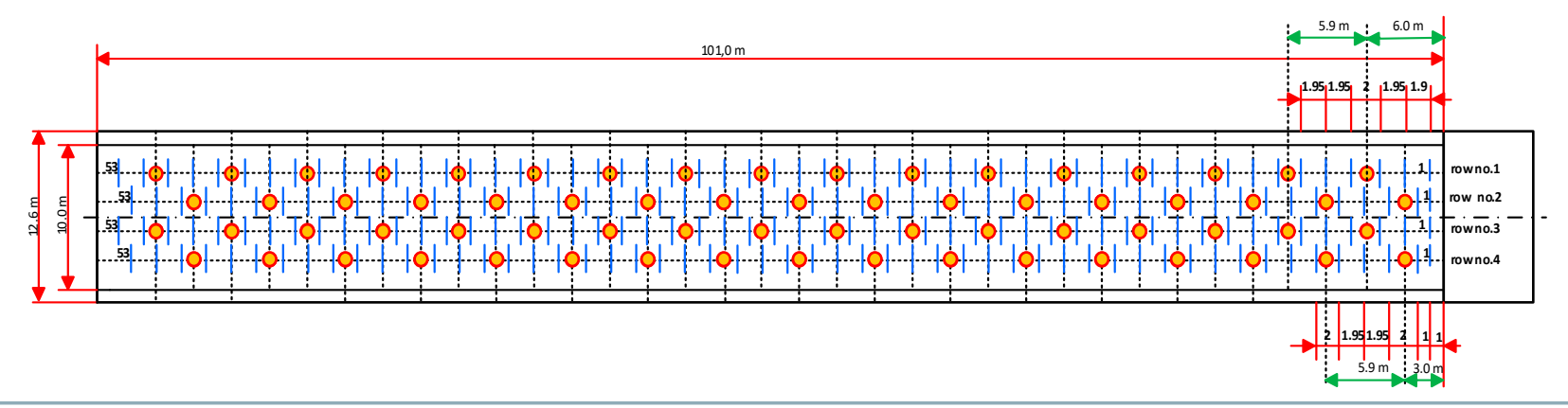

Fig. 1 Location of the luminaries and layout of the control network to measure the illumination intensity in the poultry house (circles indicate the original lighting elements, vertical bar marks represent the measurement points of the lighting) 
Table 1 Measurement results of original illumination in experimental hall

\begin{tabular}{|l||c|c|c|c|c|c|}
\hline \multirow{2}{*}{ Hall no. 3 } & $\overline{\mathbf{E}}(\mathbf{I x )}$ & $\mathbf{U}(\%)$ & $\overline{\mathbf{E}}-\mathbf{U}$ (Ix) & $\overline{\mathbf{E}}+\mathbf{U}$ (Ix) & $\mathbf{E}_{\min }$ (Ix) & $\boldsymbol{r}$ \\
\cline { 2 - 7 } & 11.59 & 14 & 9.97 & 13.21 & 7.02 & 0.60594 \\
\hline
\end{tabular}

$\overline{\mathrm{E}}$ - average illumination, $\mathrm{Ix} ; \mathrm{U}$ - permissible measurement uncertainty, \%; $r$ - uniformity of illumination $(r \geq 0.5)$

haematocrit levels was significant $(p<0.05)$ (Gharahveysi et al., 2019). Thanks to the beneficial effect of green and blue lights on performance, it is recommended to use them in broiler breeding (Gharahveysi et al., 2019; Halevy et al., 1998). In order to meet the welfare requirements, an intensity ranging from 15 to $50 \mathrm{~lx}$ was selected for the design of optimal lighting system for broiler breeding. The lighting system was designed for operation with intensity suitable for the given range. The simulation program allowed setting the colour temperature of lamps from 1 to $10,000 \mathrm{~K}$. The lifetime is $1,000 \mathrm{~h}$ for incandescent lamps, $8,000 \mathrm{~h}$ for fluorescent lamps and a significantly longer $50,000 \mathrm{~h}$ or more for LED lamps. Other advantages of LEDs are small size, specific wavelength, low thermal radiation, adjustable intensity and high photoelectric conversion efficiency. Thanks to these advantages, LEDs are ideal for supporting the broiler breeding in a controlled environment with artificial lighting (Yang et al., 2016). Luminaries are produced as standard with LED chips with colour temperature of $2800 \mathrm{~K}, 4000 \mathrm{~K}$ and $6,500 \mathrm{~K}$. By rationalizing the electricity consumption by using LED lights, it is possible to reach $40-70 \%$ savings of electric energy (Morvai et al., 2018). By designing LED lighting, there were achieved suitable light intensity; switching interval; and light colour, which will improve broiler breeding conditions and meet the requirements for more energy efficient installation at the same time.

Optimized designs of the experimental hall lighting An overview of the lighting results for proposed designs no. $1-4$ is shown in Tab. 2

\section{Design no. 1}

This design utilized the MAS LED bulb DT11W with E27 base and a colour temperature of $2,700 \mathrm{~K}$ with a luminous efficacy of $96 \mathrm{Im} \cdot \mathrm{W}^{-1}$. The quantity and layout of the luminaries is identical to the original version with a supplement of 1 luminary at the hall entrance. The total number of installed LEDs was $69 \mathrm{pcs}$. with power of $759 \mathrm{Wh}\left(0.6 \mathrm{~W} \cdot \mathrm{m}^{-2}\right)$ without the need to change the power supply.

\section{Design no. 2}

This design used the DUST LED PS $1 \times 18 / 60$-IP65 with LED light source T8-840-10W-4000K, $110 \mathrm{Im} \cdot \mathrm{W}^{-1}$ and $1 \mathrm{BC} / 6$ $8 \mathrm{~W}$ light sources with E27 base with light efficiency of $100 \mathrm{Im} \cdot \mathrm{W}^{-1}$. There were $14 \mathrm{pcs}$. of LED tubes in rows no. 1 and no. 3, and 13 pcs. of LED tubes and 2 pcs. of LED bulbs in rows no. 2 and no. 4, which were evenly distributed throughout the space. The total number of installed LED sources was $58 \mathrm{pcs}$. with power input of $572 \mathrm{Wh}\left(0.6 \mathrm{~W} \cdot \mathrm{m}^{-2}\right)$.

\section{Design no. 3}

This design used the $1 \mathrm{BC} / 6-8 \mathrm{~W}$, lamps with E27 base, colour temperature of $2,700 \mathrm{~K}$, and luminous efficacy of $100 \mathrm{Im} \cdot \mathrm{W}^{-1}$. In rows no. 1 and 3, there were used 14 pcs. of LED bulbs in each; 15 pcs. of LED bulbs were in rows no. 2 and 4 . These were evenly distributed throughout the space. The total number of installed LED sources was 58 pcs. with power input of $464 \mathrm{Wh}\left(0.6 \mathrm{~W} \cdot \mathrm{m}^{-2}\right)$.

\section{Design no. 4}

For this design, LED 118-13W-4000K-Ra80-IP65 luminaries with integrated LED, colour temperature of $4,000 \mathrm{~K}$, and luminous

Table 2 Illumination values for individual designs

\begin{tabular}{|c|c|c|c|c|c|}
\hline Design no. 1 & Min. value Ė (Ix) & Average value $\bar{E}$ (Ix) & Required value $\bar{E}$ (Ix) & Max. value Ė (Ix) & Uniformity min. 0.6 \\
\hline Corridor no. 1 & 14.60 & 19.50 & 10 & 22.20 & 0.75 \\
\hline Corridor no. 2 & 11.00 & 18.40 & 10 & 19.90 & 0.60 \\
\hline Breeding part & 19.30 & 31.90 & 20 & 35.70 & 0.61 \\
\hline Design no. 2 & Min. value É (Ix) & Average value $\bar{E}$ (Ix) & Required value $\bar{E}$ (Ix) & Max. value E (Ix) & Uniformity min. $\mathbf{0 . 6}$ \\
\hline Corridor no. 1 & 11.90 & 16.60 & 10 & 20.20 & 0.72 \\
\hline Corridor no. 2 & 14.90 & 16.80 & 10 & 21.00 & 0.84 \\
\hline Breeding part & 31.50 & 42.20 & 20 & 60.00 & 0.75 \\
\hline Design no. 3 & Min. value Ē (Ix) & Average value $\bar{E}$ (Ix) & Required value $\bar{E}$ (Ix) & Max. value Ė (Ix) & Uniformity min. 0.6 \\
\hline Corridor no. 1 & 10.90 & 13.50 & 10 & 15.60 & 0.80 \\
\hline Corridor no. 2 & 12.00 & 13.50 & 10 & 15.70 & 0.89 \\
\hline Breeding part & 23.10 & 29.80 & 20 & 43.30 & 0.78 \\
\hline Design no. 4 & Min. value Ē (Ix) & Average value $\bar{E}$ (Ix) & Required value $\bar{E}$ (Ix) & Max. value $\bar{E}$ (Ix) & Uniformity min. 0.6 \\
\hline Corridor no. 1 & 11.40 & 15.40 & 10 & 18.40 & 0.75 \\
\hline Corridor no. 2 & 13.70 & 16.40 & 10 & 20.70 & 0.83 \\
\hline Breeding part & 35.00 & 53.00 & 20 & 71.00 & 0.67 \\
\hline
\end{tabular}




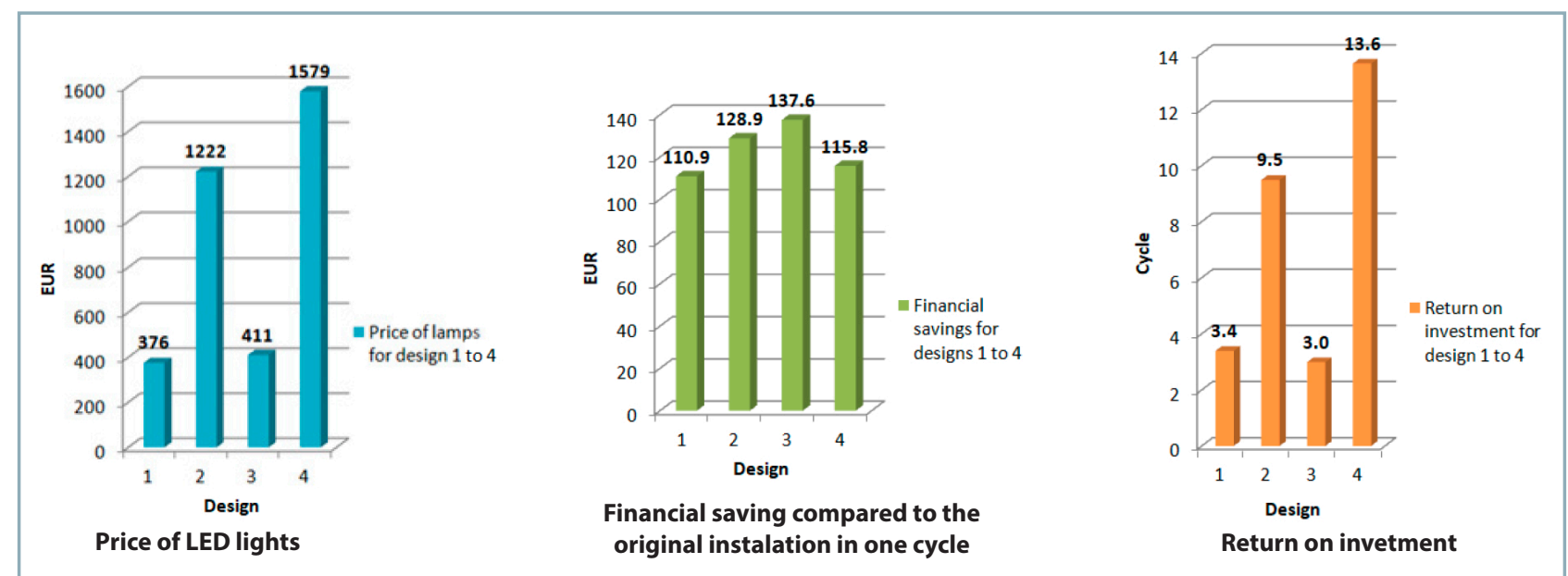

Fig. 2 Price of LED lamps, energy savings and return on investment for designs 1-4

efficacy of $100 \mathrm{Im} \cdot \mathrm{W}^{-1}$ were used. Rows no. 1 and 3 included 14 pcs. of LED lamps each and rows no. 2 and 4 included 13 pcs. of LED lamps and 2 pcs. of LED bulbs. These were evenly distributed throughout the space. Total number of installed LED sources was $58 \mathrm{pcs}$. with power input $734 \mathrm{Wh}\left(0.6 \mathrm{~W} \cdot \mathrm{m}^{-2}\right)$.

Tab. 2 shows calculated illumination and uniformity values using BuildingDesign with Wils 7.0.

\section{Consumption comparison of the original installation and designs no. 1-4}

Tab. 3 shows the consumption and price of consumed energy per cycle and eight cycles (maximal expected number of cycles per year) for designs no. 1-4 and original installation.

Price of LED lamps, financial savings and return on investment for designs no. 1-4 is shown in Fig. 2.

The original lighting switch setting is continuous lighting $(\mathrm{CL}=21 \mathrm{~h}$ on, $3 \mathrm{~h}$ off). Lighting system is off from $1: 35$ to $3: 05$, from $13: 35$ to $15: 05$ throughout the entire cycle. According to Halevy et al. (2006); Guevara et al. (2015); Yang et al. (2016), the light management is an effective tool to improve poultry performance. Switching automation and light colour for the turn will be set as shown in Fig. 2 . Continuous lighting ( $\mathrm{CL}=23 \mathrm{~h}$ on, $1 \mathrm{~h}$ off) was selected for the period from the $1^{\text {st }}$ to $6^{\text {th }}$ day. According to Gharahveysi et al. (2019), green light accelerates muscle growth and stimulates growth at an early age and blue light stimulates growth at an older age. Adjustment using green light provides a mechanism to accelerate growth (Halevy et al. 1998). Studies show that intermitted lighting (IL $=1 \mathrm{~h}$ on $-3 \mathrm{~h}$ off, $1 \mathrm{~h}$ on $-3 \mathrm{~h}$ off, $1 \mathrm{~h}$ on $-3 \mathrm{~h}$ off, $1 \mathrm{~h}$ on $-3 \mathrm{~h}$ off, $2 \mathrm{~h}$ on $-6 \mathrm{~h}$ off) is suitable for broiler breeding from the $7^{\text {th }}$ day to the cycle end (32-35 days). The difference between the average daily increase (ADG) of broilers is minimal for $C L$ and IL breeding. From the $7^{\text {th }}$ to $21^{\text {st }}$ day, $A D G=1.7 \mathrm{~g} \pm 0.9 \mathrm{~g}$ and from the $22^{\text {nd }}$ to $35^{\text {th }}$ day, $A D G=$ $0.1 \mathrm{~g} \pm 1.75 \mathrm{~g}$. Mortality at IL is lower by $0.6 \% \pm 0.22 \%$ (Rodrigues and Choct, 2019). Considering the mortality, under experimental conditions with IL and 20,000 broilers, it would be lower by $120 \pm 44$ pcs.

By selecting IL for one shift, there are achieved electricity savings necessary to illuminate the operation compared to the original installation switching mode $820.26 \mathrm{~kW}$ : 300.51 kW by design no. 1; $216.22 \mathrm{~kW}$ design no. 2; $175.39 \mathrm{~kW}$ design no. 3; $277.45 \mathrm{~kW}$ design no. 4 (56\% savings). RGB (RED, GREEN, BLUE) LED chips can be installed in the luminaries to achieve the desired light colour and intensity.

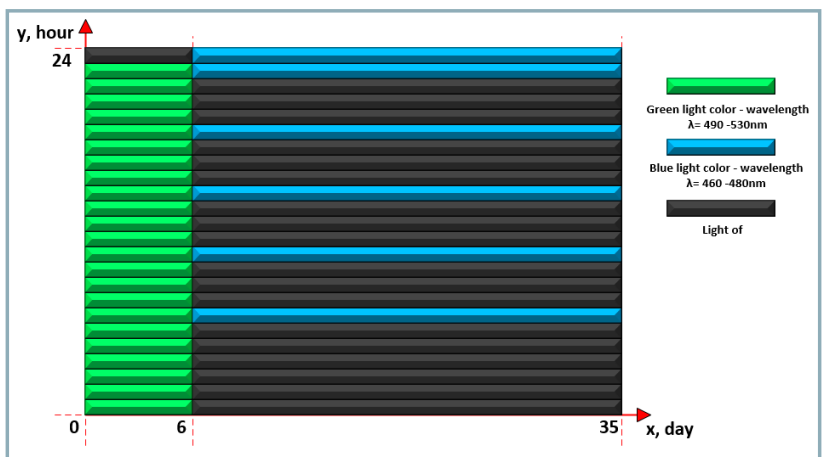

Fig. 3 Design of switching lights and light colour for broiler breeding

Table 3 Consumption and price for consumed electricity for 8 turns

\begin{tabular}{|c|c|c|c|c|c|}
\hline $\begin{array}{l}\text { Lightning } \\
\text { variants }\end{array}$ & $\begin{array}{l}\text { Power input } \\
\text { P (kWh) }\end{array}$ & $\begin{array}{l}\text { Number of hours for } \\
32 \text { days } \times 21 \mathrm{ht}(\mathrm{h})\end{array}$ & $\begin{array}{l}\text { Total consumption } \\
\text { per cycle } \mathbf{P}(\mathbf{k W h})\end{array}$ & $\begin{array}{l}\text { Price of consumed energy for } \\
\text { one cycle }-0.12 € \text { per } k W h(\epsilon)\end{array}$ & $\begin{array}{l}\text { Price per year } \\
\text { for } 8 \text { cycles }(€)\end{array}$ \\
\hline $\begin{array}{l}\text { Existing } \\
\text { installation }\end{array}$ & 2.170 & 672 & 1458.24 & 174.99 & 1399.91 \\
\hline Design no. 1 & 0.795 & 672 & 534.24 & 64.11 & 512.87 \\
\hline Design no. 2 & 0.572 & 672 & 384.38 & 46.13 & 369.01 \\
\hline Design no. 3 & 0.464 & 672 & 311.81 & 37.42 & 299.34 \\
\hline Design no. 4 & 0.734 & 672 & 493.25 & 59.19 & 473.52 \\
\hline
\end{tabular}




\section{Conclusion}

The initial illumination measurements showed that the original lighting system is not suitable in terms of the technical condition of the luminaries and light intensity with regards to the animal welfare. By designing the switching mode and light colour, both broiler welfare, as well as their more efficient weight gain, can be achieved. In terms of light intensity, all four designs are suitable in terms of animal welfare. The price of designs no. 1 and 3 is the lowest, since merely replacement of light sources with IP20 protection was taken into consideration. In comparison to design no. 1, design no. 3 is equipped with a smaller number of lamps with higher efficiency. The fastest return on investment was showed by design no. 3. Designs no. 2 and 4 used luminaries with IP 65 protection, which resulted in their four- or five-fold increased price in contrast to cheaper designs. Luminaries with IP65 protection are appropriate for the breeding environment Return on investment of design no. 2 is 9.5 cycles; return on investment of design no. 4 is 13.6 cycles. Throughout one year, there are anticipated 8 to take place. The extreme illumination values are 31.5-60 Ix for design no. 2 and 35-75 Ix for design no. 4. The luminaries in design no. 4 are fitted with adjustable ballasts (or with Digital Addressable Lighting Interface), for which the illumination intensity can be adjusted using WIFI 666 (for DALI with push button or control unit with light intensity sensors). The most advantageous alternative in the long term is design no. 4 with a consumption of $0.734 \mathrm{kWh}$, in which the switching mode can achieve savings of $56 \%$ and regulation of lighting intensity of $40 \%$ while maintaining a minimum lighting intensity of $20 \mathrm{~lx}$ (total savings up to $73.7 \%$ ). The design according to Fig. 2 can be achieved by installing RGB LED chips in IP65 luminaries. Switching and setting the colour of luminaries is possible using the application version in Microsoft Visual C \# software. The work results can be used to design the lighting at similar standardized farms.

\section{Acknowledgment}

This publication was supported by the Operational Programme Integrated Infrastructure within the project: Sustainable smart farming systems taking into account the future challenges 313011W112, cofinanced by the European Regional Development Fund.

\section{References}

BALKOVÁ, M. 2013. Assessing of daylight factor values depending on window opening structures in model room. In Acta Technologica Agriculturae, vol. 16, no. 4, pp. 95-98.

BUYSE, J. - SIMONS, P. C. M. - BOSHOUWERS, F. M. G. - DECUYPERE, E. 1996. Effect of intermittent lighting, light intensity and source on the performance and welfare of broilers. In Worlds Poultry Science Journal, vol. 52, no. 2, pp. 127-130.

GHARAHVEYSI, S. - IRANI, M. - KENARI, T. A. - MAHMUD, K. I. 2019. Effects of colour and intensity of artificial light produced by incandescent bulbs on the performance traits, thyroid hormones, and blood metabolites of broiler chickens. In Italian Journal of Animal Science, vol. 19, no. 1, pp. 1-7.

GUEVARA, B. D. M. - PECH, P. S. - ZAMORA, B. R. - NAVARETTE, S. L. F. - MAGANA, S. H. F. 2015. Performance of broilers reared under monochromatic Light Emitting Diode supplemental lighting. In Brazilian Journal of Poultry Science, vol. 17, no. 4, pp. 553-558.

HALEVY, O. - BIRAN, I. - ROZENBOIM, I. 1998. Various light source treatments affect body and skeletal muscle growth by affecting skeletal muscle satellite cell proliferation in broilers. In Comparative Biochemistry and Physiology - Part A: Molecular and Integrative Physiology, vol. 120, no.2, pp. 317-323.

HALEVY, O. - PIESTUN, Y. - ROZENBOIM, I. - YABLONKA-REUVENI, Z. 2006. In ovo exposure to monochromatic green light promotes skeletal muscle cell proliferation and affects myofiber growth in post hatch chicks. In American Journal of Physiology-Regulatory Integrative and Comparative Physiology, vol. 290, no. 4, pp. R1062-R1070.

HARTINI, S. - CHOCT, M. - HINCH, G. - KOCHER, A. - NOLAN, J. V. 2002. Effects of light intensity during rearing and beak trimming and dietary fiber sources on mortality, egg production, and performance of ISA brown laying hens. In Journal of Applied Poultry Research, vol. 11 , no. 1, pp. 104-110.

KIM, M. J. - PARVIN, R. - MUSTAG, M. M. H. - HWANGO, J. - KIM, J. H. - NA, J. C. - KIM, D. W. - KANG, C. D. - CHO, K. O. - YANG, C. B. $\mathrm{CHOI}, \mathrm{H}$. C. 2013. Growth performance and haematological traits of broiler chickens reared under assorted monochromatic light sources. In Poultry Science, vol. 92, no. 6, pp. 1461-1466.

LEWIS, P. D. - GOUS, R. M. 2007. Broilers perform better on short or step-up photoperiods. In South African Journal of Animal Sciences, vol. 37, no. 2 , pp. $90-96$.

LIEN, R. J. - HESS, J. B. - MCKEE, S. R. - BILGILI, S. F. - TOWNSEND, J. C. 2007. Effect of light intensity and photoperiod on live performance, heterophil-to-lymphocyte ratio, and processing yields of broilers. In Poultry Science, vol. 86, no. 7, pp. 1287-1293.

MATAUSCHEK, A. - PIEPHO, H. P. - BESSEI, W. 2006. The effect of feather eating on feed passage in laying hens. In Poultry Science, vol. 85 , no. 1 , pp. 21-25.

MIHINA, Š. - KAŽIMÍROVÁ, V. - COPLAND, T. A. 2012. Technology for Farm Animal Husbandry. Nitra : Slovak University of Agriculture in Nitra, 99 pp.

MORVAI, P. - ZITŇÁK, M. - PAULOVIČ, S. 2018. Rationalization of electricity consumption in households. In Acta Technologica Agriculturae, vol. 21, no. 2, pp. 69-74.

MORVAI, P. - ŽITNÁK, M. 2019. Backup diesel generator calculation for farms. In Rural Buildings in European Regions: RUBER 2019, pp. 38-42.

NEWBERRY, R. C. 1999. Exploratory behaviour of young domestic fowl. In Applied Animal Behaviour Science, vol. 63, no. 4, pp. 311-321.

OLANREWAJU, H. A. - THAXTON, J. P. - DOZIER III, W. A. - PURSWELL, J. - ROUSH, W. B. - BRANTON, S. L. 2006. A review of lighting programs for broiler production. In International Journal of Poultry Science, vol. 5, no. 4, pp. 301-308.

OLANREWAJU, H. A. - MILLER, W. W. - MASLIN, W. R. - COLLIER, S. D. 2011. Effect of varying light intensity on welfare indices of broiler chickens grown to heavy weights. In Poultry Science, vol. 10, no. 8, pp. 590-596.

PITESKY, M. - THORNGREN, A. - NIEMEIER, D. 2019. Feeding and lighting practices on small-scale extensive pastured poultry commercial farms in the United States. In Poultry Science, vol. 98, no. 2, pp. 785-788.

RIBER, A. B. - WEERD, H. A - JONG, I. C. - STEENFELDT, S. 2018. Review of environmental enrichment for broiler chickens. In Poultry Science, vol. 97, no. 2, pp. 378-396.

RODRIGUES, I. - CHOCT, M. 2019. Feed intake pattern of broiler chickens under intermittent lighting: Do birds eat in the dark? In Animal Nutrition, vol. 5, no. 2, pp. 174-178.

XIE, D. - WANG, Z. X. - DONG, Y. L. - CAO, J. - WANG, J. F. - CHEN, J. L. - CHEN, Y. X. 2008. Effects of monochromatic light on immune response of broilers. In Poultry Science, vol. 87, no. 8, pp. 1535-1539. YANG, Y. F. - YU, Y. H. - PAN, J. M. - YING, Y. B. - ZHOU, H. 2016. A new method to manipulate broiler chicken growth and metabolism: Response to mixed LED light system. In Scientific Reports, vol. 6, no. 2597.

STN EN 12464-1: 2011. Light and lighting. Lighting of workplaces. Part 1: Indoor workplaces. (In Slovak: Svetlo a osvetlenie. Osvetlenie pracovísk. Čast' 1: Vnútorné pracoviská).

STN EN 13032-1+A1: 2012. Light and lighting. Measurement of photometric data of lamps and luminaries. Part 1: Measurement and file form. (In Slovak: Svetlo a osvetlenie. Meranie fotometrických údajov svetelných zdrojov a svietidiel. Čast' 1: Meranie a formulár súborov). 